\title{
Massed and Spaced Learning in Honeybees: The Role of CS, US, the Intertrial Interval, and the Test Interval
}

\author{
Randolf Menzel, ${ }^{1}$ Gisela Manz, Rebecca Menzel, and Uwe Greggers \\ Freie Universität Berlin, Fachbereich Biologie/Chemie/Pharmazie-Neurobiologie, 14195 Berlin, Germany
}

\begin{abstract}
Conditioning the proboscis extension reflex of harnessed honeybees (Apis mellifera) is used to study the effect temporal spacing between successive conditioning trials has on memory. Retention is monitored at two long-term intervals corresponding to early ( 1 and $2 \mathrm{~d}$ after conditioning) and late long-term memory (3 and 4 d). The acquisition level is varied by using different conditioned stimuli (odors, mechanical stimulation, and temperature increase at the antenna), varying strengths of the unconditioned stimulus (sucrose), and various numbers of conditioning trials. How learning trials are spaced is the dominant factor both for acquisition and retention, and although longer intertrial intervals lead to better acquisition and higher retention, the level of acquisition per se does not determine the spacing effect on retention. Rather, spaced conditioning leads to higher memory consolidation both during acquisition and later, between the early and long-term memory phases. These consolidation processes can be selectively inhibited by blocking protein synthesis during acquisition.
\end{abstract}

Learning trials distributed over time lead to better memory than learning trials squeezed into short periods of time. Jost (1897), who elaborated on the original findings by Ebbinghaus (1885), was the first to formulate a theory supposing a contraintuitive, even perplexing interrelation between short-term forgetting and long-term strengthening of memory. In his words, "Given equal associative strength, the older the memory trace at the time of learning repetition, the less forgetting over the long term." The "paradox of spaced practice" (Björk and Allen 1970) was assumed to lie in the fact that longer intervals between learning trials should lead to less memory on a trial-to-trial basis, but multiple units of less memory should finally lead to stronger long-term memory.

The conceptual basis for interpreting the spacing effect is the notion of memory dynamics (James 1890; Müller and Pilzecker 1900; Squire 1987). Each learning trial is thought to initiate an intrinsic process of memory formation that leads to final memory by constructive (memory consolidation) and destructive (forgetting) processes. Studies of many species have shown that when training involves multiple trials, the time interval between trials is an important variable in the efficacy of accumulating training effects and the strength of retention (Carew et al. 1972; Fanselow and Tighe 1988; Tully et al. 1994; Spieler and Balota 1996; Ko-

${ }^{1}$ Corresponding author.

E-MAIL menzel@neurobiologie.fu-berlin.de; FAX 49-30-83855455.

Article and publication are at http://www.learnmem.org/cgi/doi/ $10.1101 / \mathrm{lm} .40001$. gan et al. 1997; Hermitte et al. 1999; Muzzio et al. 1999; Beck et al. 2000; Wu et al. 2001). The paradigms tested were taste aversion conditioning, fear conditioning, blink conditioning, olfactory aversion training, episodic priming, and learning nonsense syllables. In addition to humans, a wide range of animals was studied (Drosophila, the marine mollusks Aplysia and Hermissenda, the crab Chasmagnathus, rats, and rabbits). The dynamics and interdependence of the constructive and destructive (forgetting) memory processes, and, particularly, their reliance on external and internal parameters are, however, mostly unknown. Because the spacing effect is a robust behavioral phenomenon and calls for a mechanistic explanation, it would be desirable to parameterize conditions controlling the effect. In particular, the relationship between parameters controlling the acquisition process and retention over longer test intervals has not yet been systematically studied. Manipulations of the learned stimuli, the strength of reinforcement, and training schedules lead to different levels of initial learning and need to be examined with respect to their effect on the spacing phenomenon.

In the past honeybees (Apis mellifera) have been used successfully to describe memory dynamics after single- or multiple-trial appetitive learning both in color learning by free-flying bees and in olfactory proboscis conditioning (for review, see Menzel 1999; Menzel and Müller 1996). For free-flying honeybees it was discovered that a single conditioning trial leads to a dual-phase retention function with high retention at very short ( $<1 \mathrm{~min})$ and at longer $(>5 \mathrm{~min})$ intervals, and with a dip around $3 \mathrm{~min}$, indicating a consolidation process in the time range of several minutes after

LEARNING \& MEMORY 8:198-208 @ 2001 by Cold Spring Harbor Laboratory Press ISSN1072-0502/01 \$5.00

$$
\begin{array}{lllllllllllllll}
\text { L } & E & A & R & N & I & N & G & \mathcal{Z} & M & E & M & O & R & Y \\
\text { www.learnmem.org } & & &
\end{array}
$$


learning. Multiple learning trials facilitate consolidation into long-lasting memory (more than several days). Consolidation is accompanied by increasing resistance to extinction (Menzel 1990) and reduced preparedness for reversal learning (Menzel 1979). Furthermore, the time course of consolidation was found to depend on the strength of reward (Menzel 1968). Using the olfactory conditioning paradigm, one can demonstrate the same dual-phase time course of retention as in free-flying bees, and the effects on resistance to extinction and reversal learning (Menzel 1990). In addition, Smith (1991) found that generalization between odors after a single odor conditioning trial is different in the short (30 sec) and longer term (15-30 min) ranges, indicating a change in memory content during consolidation (see also Menzel 1990). In earlier studies (Bitterman et al. 1983; Sandoz et al. 1995) multiple learning trials with either very long or very short intertrial intervals (ITIs) between 1 and $20 \mathrm{~min}$ did not lead to different acquisition and retention. However, an analysis that also tested intermediate ITIs found a nonmonotonous dependence of long-term memory (LTM) on ITI (Gerber et al. 1998). LTM after $4 \mathrm{~d}$ is high for short (1 min) and long (20 min) ITIs, but low for an intermediate (3 min) ITI. Interestingly, retention after $1 \mathrm{~d}$ was not affected by the ITI, leading to the working hypothesis that 1-d and 4-d retention might have different mechanistic bases. Concerning the relation of retention and acquisition, the authors (Gerber et al. 1998) argued that in their data set, differences in the levels of acquisition and retention are doubly dissociated, and that acquisition performance therefore does not translate one-to-one into retention test performance. The nonmonotonous trial spacing effect is therefore independent of the process of acquisition, and does not depend on differences in short-term retention, but may depend on a process of consolidation between trials that is specifically obstructed for ITIs of $3 \mathrm{~min}$. Such a consolidation process affects only late LTM, a long-term memory phase that develops after $1 \mathrm{~d}$, and requires protein synthesis (Grünbaum and Müller 1998; Wüstenberg et al. 1998; Menzel 1999).

These results support the conclusion that the time-dependence of retention is strongly related to the spacing effect. Because the level of retention also depends on parameters influencing acquisition (e.g., the salience of the conditioned stimulus, CS; the strength of the unconditional stimulus, US; the number of CS/US pairings), one may ask whether the level of acquisition (instead of or in addition to the timing of repeated trials) may control consolidation. We accordingly manipulated acquisition over a wide range by varying the CS and US strengths and the number of acquisition trials. We find that the spacing of learning trials is the dominant factor both for acquisition and retention. In addition, we find a prominent difference in retention at the late long-term memory phase ( $>2 \mathrm{~d}$ after conditioning). Spaced conditioning trials induce a consolidation process that can be selectively inhibited by blocking protein synthesis during acquisition.

\section{RESULTS}

\section{Effect of Intertrial Interval}

In a first series of experiments we tested 3 ITIs: $30 \mathrm{sec}, 3$ min, and $10 \mathrm{~min}$ (Fig. 1), using carnation as the CS and the standard US (1.25 M sucrose solution), and found that all responses taken together for the acquisition process indicate that acquisition scores depend on ITI $\left(\chi^{2}=6.198\right.$, $P<0.04$, df $=2$ ). A more specific analysis indicates that acquisition in the 30-sec ITI group differs from that of both the 3-min and the 10-min ITI groups taken together $\left(\chi^{2}=5.68\right.$, $P<0.02$, df $=1$ ). Plateau levels of acquisition also depend on ITI $\left(\chi^{2}=7.274, P<0.03\right.$, df $\left.=2\right)$, and, more specifically, the 30-sec ITI differs from the 3-min and 10-min ones $\left(\chi^{2}=9.71, \quad P<0.001, \quad \mathrm{df}=1\right)$. Comparing all retention scores at all three test times ( $30 \mathrm{~min}, 1 \mathrm{~d}, 4 \mathrm{~d})$, one finds that retention depends on ITI $\left(\chi^{2}=10.156, P<0.006\right.$, df $\left.=2\right)$. More specifically, retention scores for the 30-sec ITI group differ from those for the 3-min and 10-min ITI groups $\left(\chi^{2}=7.07, P<0.008, \mathrm{df}=1\right)$, and those for the 10 -min ITI group differ from those of both the 30-sec and 3-min ITI groups taken together $\left(\chi^{2}=7.59, P<0.006\right.$, df $\left.=1\right)$. An analysis of the retention scores at day 1 and at day 3 reveals no significant effect of ITI on day 1 after conditioning, but a significant dependence on ITI at day $3\left(\chi^{2}=14.78\right.$, $P<0.001$, df $=2$ ). More specific evaluations indicate that the 30-sec ITI group differs from the 3-min and 10-min ITI groups $\left(\chi^{2}=32.27, P<0.0001\right.$, df $\left.=1\right)$, and the 10-min ITI group differs from the 30-sec and 3-min ITI groups taken together $\left(\chi^{2}=4.40, P<0.035, \mathrm{df}=1\right)$.

In subsequent experiments we found that ITIs longer than $10 \mathrm{~min}$ (20 and $30 \mathrm{~min}$ tested) gave results similar to those from 10-min ITIs, for both acquisition and retention (data not shown). Therefore we focused our experiments

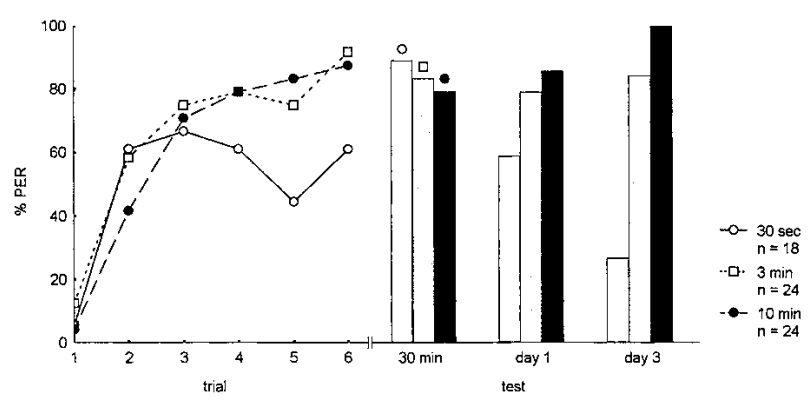

Figure 1 Acquisition and retention for three ITI groups, $30 \mathrm{sec}, 3$ $\mathrm{min}$, and $10 \mathrm{~min}$. For statistical evaluation, see text. The ordinate gives the percentage of animals responding to the CS. The abscissa on the left side of the figure gives the conditioning trials. ( $-\mathrm{O}-$ ) ITI $30 \mathrm{sec}$; (- $\square-$ ) ITI 3 min; (--) ITI $10 \mathrm{~min}$. The animals in the three groups were tested $30 \mathrm{~min}, 1 \mathrm{~d}$, and $3 \mathrm{~d}$ after conditioning, respectively. $n$ gives the number of animals.

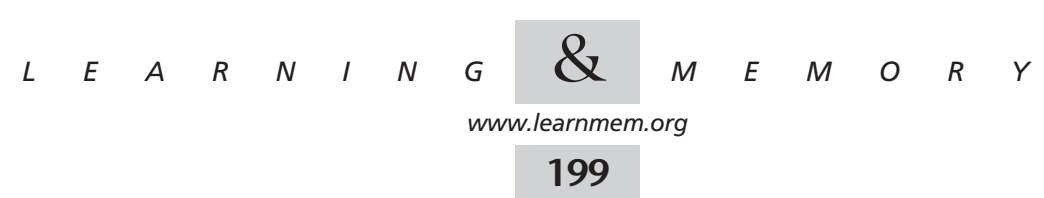


Table 1. Effect of Number of Acquisition Trials, CS, and US Strength

\begin{tabular}{|c|c|c|c|c|c|c|c|c|c|c|c|c|}
\hline \multirow{3}{*}{$\begin{array}{l}\text { Exp. } \\
\text { no. }\end{array}$} & \multirow[b]{3}{*}{ CS } & \multirow[b]{3}{*}{ US } & \multirow{3}{*}{$\begin{array}{c}\text { Conditioning } \\
\text { trials }\end{array}$} & \multicolumn{7}{|c|}{ Retention tests } & \multirow[b]{3}{*}{$\mathrm{N}$} & \multirow[b]{3}{*}{ Comments } \\
\hline & & & & \multicolumn{2}{|c|}{$\begin{array}{c}\% \text { PER } \\
\text { acquisition }\end{array}$} & \multicolumn{2}{|c|}{$\begin{array}{c}\text { Early LTM } \\
\text { \% PER }\end{array}$} & \multicolumn{2}{|c|}{$\begin{array}{l}\text { Late LTM } \\
\% \text { PER }\end{array}$} & \multirow{2}{*}{$\begin{array}{c}\text { Test } \\
\text { groups }\end{array}$} & & \\
\hline & & & & massed & spaced & massed & spaced & massed & spaced & & & \\
\hline 1 & carnation & $1.25 \mathrm{~m}$ & 5 & $48 \%$ & $81 \%$ & $36 \%$ & $72 \%$ & $29 \%$ & $86 \%$ & same & 62 & \\
\hline 2 & propionic acid & $1.25 \mathrm{~m}$ & 5 & $73 \%$ & $86 \%$ & $50 \%$ & $81 \%$ & $35 \%$ & $81 \%$ & same & 99 & \\
\hline 3 & propionic acid & $1.25 \mathrm{~m}$ & 5 & $23 \%$ & $45 \%$ & $20 \%$ & $50 \%$ & $11 \%$ & $52 \%$ & same & 77 & \\
\hline 4 & propionic acid & $1.25 \mathrm{~m}$ & 5 & $62 \%$ & $90 \%$ & $48 \%$ & $90 \%$ & $45 \%$ & $96 \%$ & same & 58 & \\
\hline 5 & propionic acid & $1.25 \mathrm{~m}$ & 5 & $60 \%$ & $64 \%$ & $20 \%$ & $79 \%$ & $10 \%$ & $86 \%$ & same & 24 & \\
\hline 6 & hexanol & $1.25 \mathrm{~m}$ & 5 & $54 \%$ & $79 \%$ & $46 \%$ & $87 \%$ & $44 \%$ & $82 \%$ & same & 121 & \\
\hline 7 & hexanol & $0.5 \mathrm{~m}$ & 5 & $59 \%$ & $71 \%$ & $59 \%$ & $79 \%$ & $59 \%$ & $88 \%$ & same & 58 & \\
\hline 8 & hexanol & $2.5 \mathrm{~m}$ & 5 & $59 \%$ & $93 \%$ & $50 \%$ & $78 \%$ & $56 \%$ & $100 \%$ & same & 59 & \\
\hline 9 & carnation & $1.25 \mathrm{~m}$ & 5 & $72 \%$ & $97 \%$ & $48 \%$ & $81 \%$ & - & - & different & 60 & $\begin{array}{l}\text { only early } \\
\text { LTM tested }\end{array}$ \\
\hline 10 & carnation & $1.25 \mathrm{~m}$ & 5 & $7 \%$ & $64 \%$ & - & - & $29 \%$ & $68 \%$ & different & 39 & $\begin{array}{l}\text { only late } \\
\text { LTM tested }\end{array}$ \\
\hline 11 & propionic acid & $1.25 \mathrm{~m}$ & 8 & $29 \%$ & $70 \%$ & $19 \%$ & $43 \%$ & - & - & different & 59 & \\
\hline & & & & $25 \%$ & $100 \%$ & - & - & $39 \%$ & $86 \%$ & & & \\
\hline 12 & hexanol & $1.25 \mathrm{~m}$ & 12 & $21 \%$ & $52 \%$ & - & - & $46 \%$ & $65 \%$ & different & 51 & $\begin{array}{l}\text { only late } \\
\text { LTM tested }\end{array}$ \\
\hline 13 & mechanical & $1.25 \mathrm{~m}$ & 8 & $53 \%$ & $75 \%$ & $53 \%$ & $56 \%$ & - & - & different & 59 & \\
\hline & stimulus & & & $63 \%$ & $83 \%$ & - & - & $31 \%$ & $75 \%$ & & & \\
\hline 14 & infrared & $1.25 \mathrm{~m}$ & 8 & $47 \%$ & $59 \%$ & $43 \%$ & $50 \%$ & - & - & different & 89 & \\
\hline & stimulus & & & $51 \%$ & $57 \%$ & - & - & $30 \%$ & $60 \%$ & & & \\
\hline
\end{tabular}

on two ITI groups, massed-trained animals with 30-sec ITIs, and spaced-trained animals with 10-min ITIs.

\section{The Effect of Number of Acquisition Trials, CS, and US Strength}

The other 14 experiments (Table 1) were designed such that the asymptotic level of acquisition varied between 5\% and $97 \%$ by applying different numbers of acquisition trials, different US strength, and different CSs. Running the experiments at various times of the year, and with different animals from different colonies, introduced additional uncontrollable parameters that led to different levels of acquisition. Two kinds of retention tests were performed. Animals were tested either twice during both the early and the late long-term memory phase (cumulative testing, called same group in Table 1), or only once, during either the early or the late long-term memory phase (no cumulative testing, called different groups in Table 1). The rationale for these two kinds of retention tests is that cumulative testing (same groups) may cause extinction, which, in turn, may affect retention differently in massed- and spaced-conditioned animals. It appears that extinction is a rather weak phenomenon under our test conditions, and although all results reported here apply equally well to both test groups, we analyzed the two groups separately, first the eight same experiments (experiments 1-8) and then the six different experiments (experiments 9-14).

Figure 2 gives the results for the same group (experi- ments 1-8). Massed conditioning leads to lower acquisition scores than spaced conditioning. (Taking all scores to-
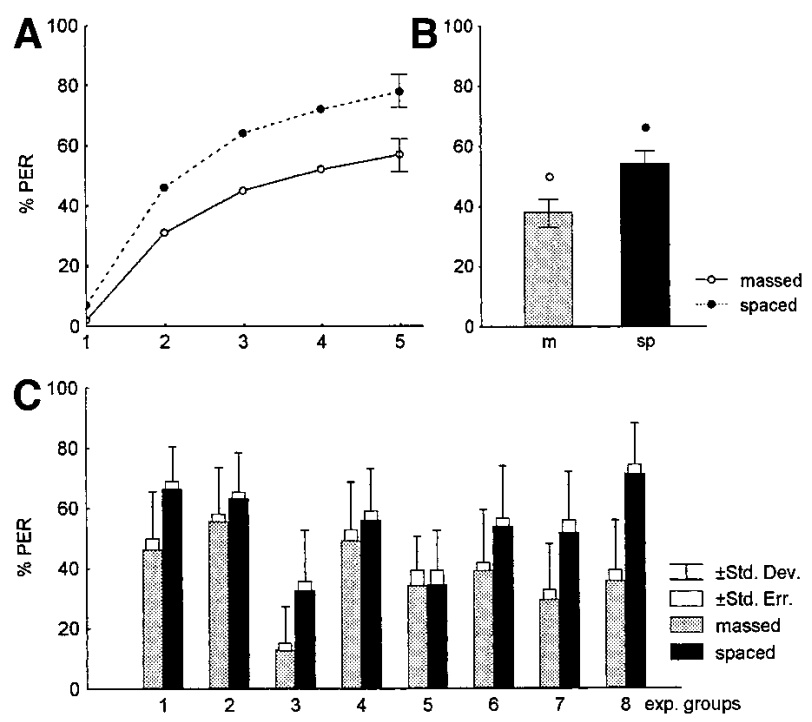

Figure 2 Acquisition process of experiments 1-8 (called same groups in Table 1). (A) The average acquisition function for the massed-conditioned (-O-) and spaced-conditioned (----) groups, and the error bars for trial 5. (B) Average scores for the overall acquisition process of the massed- and spaced-conditioned groups. (C) Separate scores for the acquisition process of the eight massed- and spaced-conditioned groups. For group numbers, see Table 1.

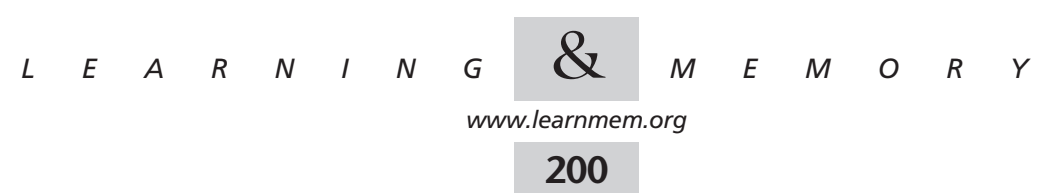


gether, $\chi^{2}=10.9$, N.S., $\mathrm{df}=14$. This indicates that our models are valid, and therefore the data are not mutually independent; see Materials and Methods, Statistics.) Analyzing only the last acquisition trial as an indicator of asymptotic performance, one also finds a dependency on ITI $\left(\chi^{2}=30.22, P<0.0001, \mathrm{df}=1\right)$ as well as on the overall acquisition process $\left(\chi^{2}=13.92 . P<0.0002\right.$, $\left.\mathrm{df}=1\right)$. Figure 2C shows the individual acquisition scores for the eight experiments. Acquisition is significantly different among these eight groups $\left(\chi^{2}=31.53, P<0.0001\right.$, df $\left.=7\right)$. This might reflect an effect of the varied parameters (the CS) or that of uncontrollable parameters (see above). Independent of the individual acquisition process, spaced conditioning leads to significantly higher scores than massed conditioning in seven out of eight cases.

Independence can be rejected for the retention scores taken together for both test intervals and ITI groups $\left(\chi^{2}=20.1\right.$, N.S., $\left.\mathrm{df}=35\right)$. More specifically, retention scores depend on ITI $\left(\chi^{2}=116.33, P<0.00001\right.$, df $\left.=1\right)$. A comparison between the two ITI groups at the early LTM interval shows a significant difference $\left(\chi^{2}=41.23\right.$, $P<0.00001, \mathrm{df}=1)$. The same holds true for the late LTM interval $\left(\chi^{2}=72.29, P<0.00001\right.$, df $\left.=1\right)$. Retention scores are plotted in Figure 3 for all eight same experiments taken

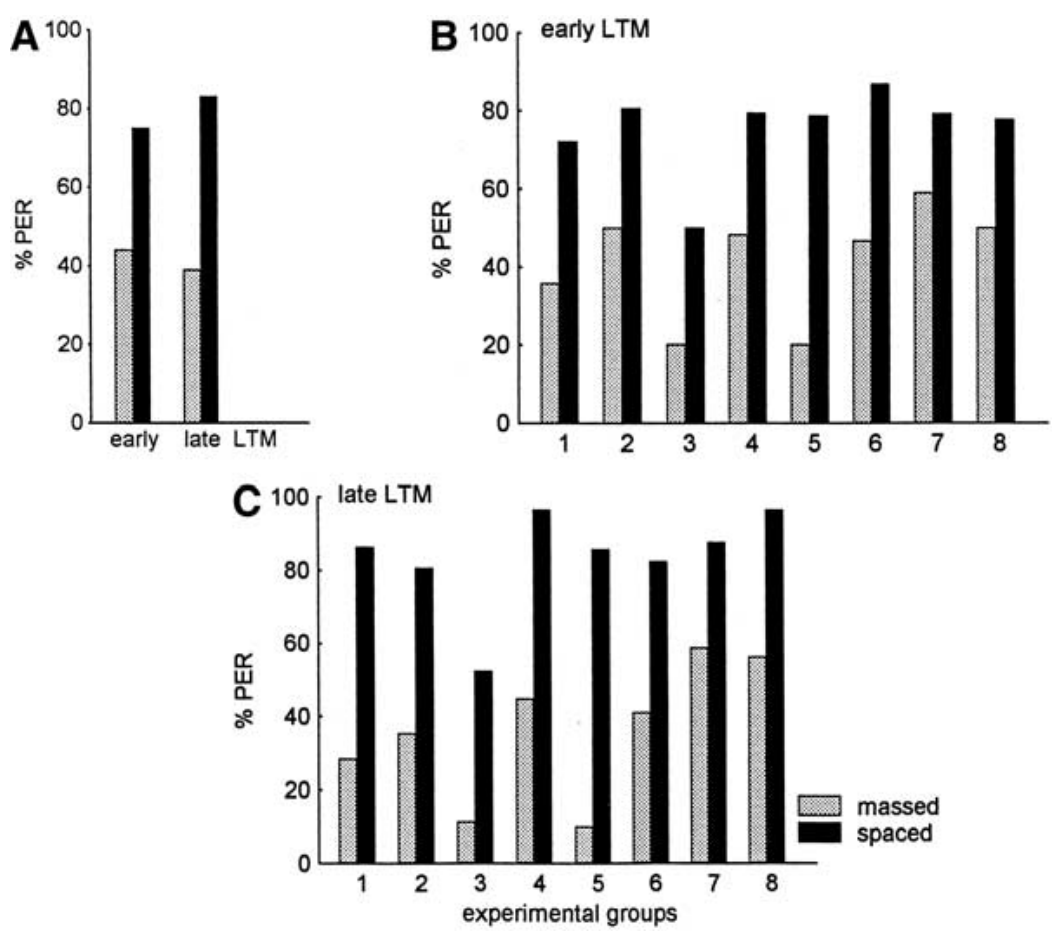

Figure 3 Retention scores of experiments 1-8 (called same groups in Table 1). (A) Overall retention scores of the massed- and spaced-conditioned groups at the two test intervals (early LTM: 1 and $2 \mathrm{~d}$ after conditioning; late LTM: 3 and $4 \mathrm{~d}$ after conditioning). (B) Separate retention scores of the eight massed and spaced groups at the early LTM test interval (1 or $2 \mathrm{~d}$ ). (C) Separate retention scores of the eight massed and spaced groups at the late LTM test interval ( 3 or $4 \mathrm{~d}$ ). together (Fig. 3A) and for the eight experiments separately (Fig. 3B). In the latter case the test intervals are pooled, because one can see from Figure $3 \mathrm{~A}$ that no significant difference is found between the two test intervals. However, there appears to be a tendency toward improvement in retention over time after spaced conditioning and a reduction in retention over time after massed conditioning. In contrast to the acquisition process, retention scores are not significantly different between the eight spaced-conditioned groups ( $\chi^{2}=3.131$, N.S.; $\left.d f=7\right)$, possibly because retention scores reach a high level of saturation. This may also be taken as an indication for improvement over time. The massed-conditioned groups, however, are much more variable. Therefore, we searched for a correlation between acquisition and retention scores but did not detect any correlation. This indicates that retention after massed conditioning might be controlled by a parameter not affecting acquisition, which does not seem to be varied by our experimental protocol.

A similar analysis was performed with the group of six different experiments (Table 1, experiments 9-14; Fig. 4). Taking the scores for the acquisition process together for those animals that were later tested during early LTM (left two columns in Fig. 4A) one finds that the data are not mutually independent $\left(\chi^{2}=4.1, \quad\right.$ N.S., $\mathrm{df}=6$; this is a significant effect because $P>0.05$ rejects independence; Fig. $4 \mathrm{~A}$ ); the same applies for the acquisition scores of the animals that were later tested during late LTM (right two columns in Fig. 4A; $\chi^{2}=11.44$, N.S., $\mathrm{df}=8$ ). Analyzing acquisition during massed and spaced conditioning one also finds significantly higher acquisition during spaced conditioning than during massed conditioning in both groups (Fig. 4A, left two columns, $\chi^{2}=10.43, P<0.001$, df $=1$; right two columns, $\chi^{2}=14.80$, $P<0.0001$, df $=1$ ). The retention scores at both the early and the late LTM intervals (Fig. 4B,C) taken together are mutually independent (early LTM, Fig. $4 \mathrm{~B}, \chi^{2}=3.94$, N.S., df $=6$; late LTM, Fig. $4 \mathrm{C}, \chi^{2}=4.15$, N.S., $\mathrm{df}=12$ ). Again analyzing retention scores after massed and spaced conditioning, one finds significantly higher retention scores after spaced conditioning at both test intervals (early LTM, $\chi^{2}=5.96, P<0.02$, df $=1 ; \chi^{2}=16.77, P<0.00001$, df = 1). In both test groups, therefore, same and different spaced conditioning leads to significantly higher scores than massed conditioning. A tendency is seen for a greater difference between massed- and spacedconditioned groups at the late LTM interval

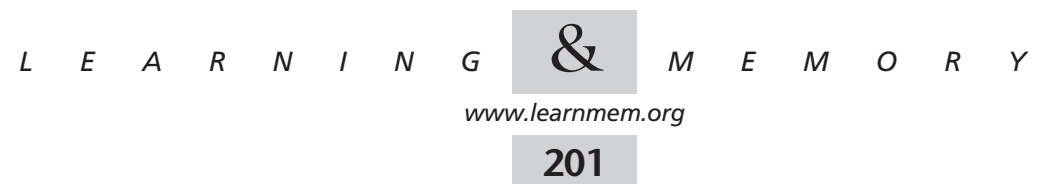




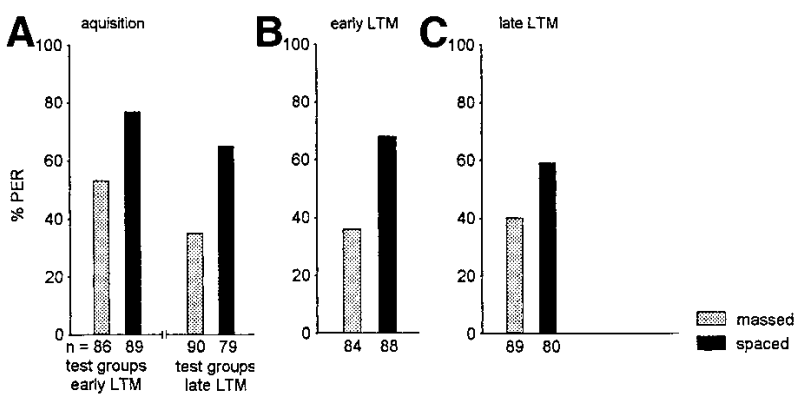

Figure 4 Acquisition and retention scores of experiments 9-14 (called different groups in Table 1). (A) Overall acquisition scores of the massed- and spaced-conditioned groups. (B) Overall retention scores of the massed-and spaced-conditioned groups at the early LTM interval (1 and $2 \mathrm{~d}$ after conditioning). (C) Overall retention scores of the massed- and spaced-conditioned groups at the late LTM interval (3 and $4 \mathrm{~d}$ after conditioning).

as compared to the early LTM interval (in early LTM two out of four cases show significantly higher scores in spaced conditioned animals; in late LTM all five groups of spacedconditioned animals have significantly higher retention scores).

Three parameters were varied with the aim to elucidate any selective effect of trial spacing on acquisition and/ or retention. These parameters were the number of acquisition trials, the salience of CS, and US strength (Table 1).

Different numbers of acquisition trials and different CSs (but same US strength, experiments 1-6, 9-14) lead to different asymptotic levels of acquisition, but acquisition after massed conditioning always lies below that after spaced conditioning for corresponding trial numbers and CSs. Retention scores are also always lower after massed conditioning irrespective of the absolute level of retention. There are two trends visible in the development of retention over time: (1) retention scores after massed conditioning tend to be lower at the late LTM interval as compared to the early LTM interval (lower in seven cases, no change in two cases, higher in one case), and (2) retention scores after spaced conditioning tend to be higher at the late LTM interval as compared to the early LTM interval (higher in six cases, no change in two cases, lower in one case). Therefore, no effect of the absolute level of acquisition and retention is found. The role of CS salience was studied using different olfactory stimuli, a mechanical stimulus to the antennae (brushing), and an infrared stimulus pointed toward the head and antennae. Propionic acid was included in the study because there is some indication that it has aversive properties, and may therefore have a different salience as compared to the appetitive odors carnation and hexanol. Salience may express itself in selective effects on acquisition and retention after massed and spaced conditioning besides causing different acquisition and retention scores. Again we find no additional effects that might indicate a specific role of CS salience. For propionic acid we also found no significant difference with respect to acquisition or retention.

The role of US strength was tested by running two experimental groups in parallel, one with a low (experiment 7) and one with a high (experiment 8) concentration of sucrose solution. Over all four test groups we find a significant difference in acquisition $\left(\chi^{2}=4.17\right.$, N.S., $\left.\mathrm{df}=4\right)$. A comparison between the respective groups shows that the ITI parameter (massed, spaced) is the determining factor $\left(\chi^{2}=7.31, P<0.01, \mathrm{df}=1\right)$. Therefore, we do not find a dependence on the US strength $\left(\chi^{2}=4.53\right.$, N.S., $\left.\mathrm{df}=3\right)$.

Retention scores show a tendency for better memory after spaced conditioning in both US groups, and an improvement over time for the spaced-conditioned groups in both US groups (Fig. 3B,C; experiments 7 and 8).

It therefore appears that the general effects of spaced and massed conditioning are found for all levels of acquisition, independent of whether controllable parameters such as trial number, CS salience, or US strength, or uncontrollable variables such as the season, colony conditions, weather conditions, or natural foraging conditions lead to different levels of acquisition.

\section{Protein Synthesis Inhibition}

Next we asked whether massed and spaced conditioning leads to different memories with respect to its dependence on protein synthesis. This is a particularly relevant question for honeybees, because protein synthesis-dependent memories develop rather slowly and lead to a reduction of retention after blocking protein synthesis during or shortly after conditioning only for intervals longer than $2 \mathrm{~d}$ (Grünbaum and Müller 1998; Wüstenberg et al. 1998). Figure 5, A and B, shows that acquisition is not affected by blocking transcription during acquisition. This applies to all experimental series performed. All data on acquisition taken together indicate that the data are mutually independent $\left(\chi^{2}=19.35\right.$, N.S., $\mathrm{df}=28$ ), and that the determining factor is massed/ spaced conditioning (acquisition is significantly higher after spaced conditioning: $\chi^{2}=12.07, P<0.0005$, df $=1$ ). Analyzing retention, we find mutual independence for all scores in the three experiments compiled in Figure 5, C and D $\left(\chi^{2}=7.65\right.$, N.S., $\left.\mathrm{df}=8\right)$. The statistical analysis reveals for all control groups that massed/spaced conditioning is the determining parameter $\left(\chi^{2}=6.03, P<0.05, \mathrm{df}=1\right)$. The statistical analysis reveals for all animals treated with actinomycin D (ActD groups) that early/late retention is the determining parameter $\left(\chi^{2}=9.77, P<0.005\right.$, df $\left.=1\right)$. Analyzing the effect of ActD for the massed-conditioned groups of all three experiments at both test intervals taken together, we find significantly lower retention scores in the ActD groups $\left(\chi^{2}=5.13, P<0.02, \mathrm{df}=1\right)$; the same applies for the spaced-conditioned groups $\left(\chi^{2}=22.47, P<0.0001\right.$, df $\left.=1\right)$. However, separated for the test intervals, we find that the

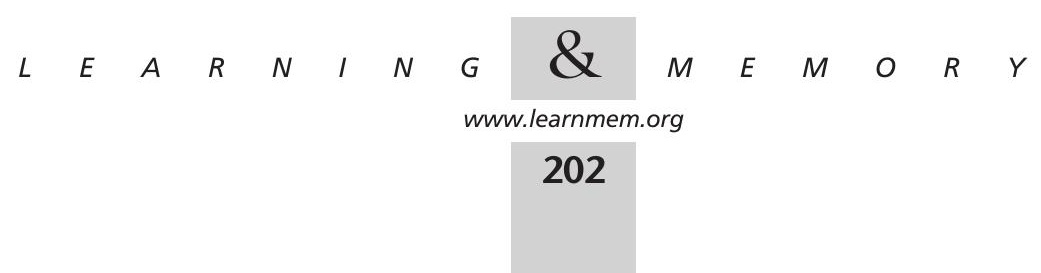




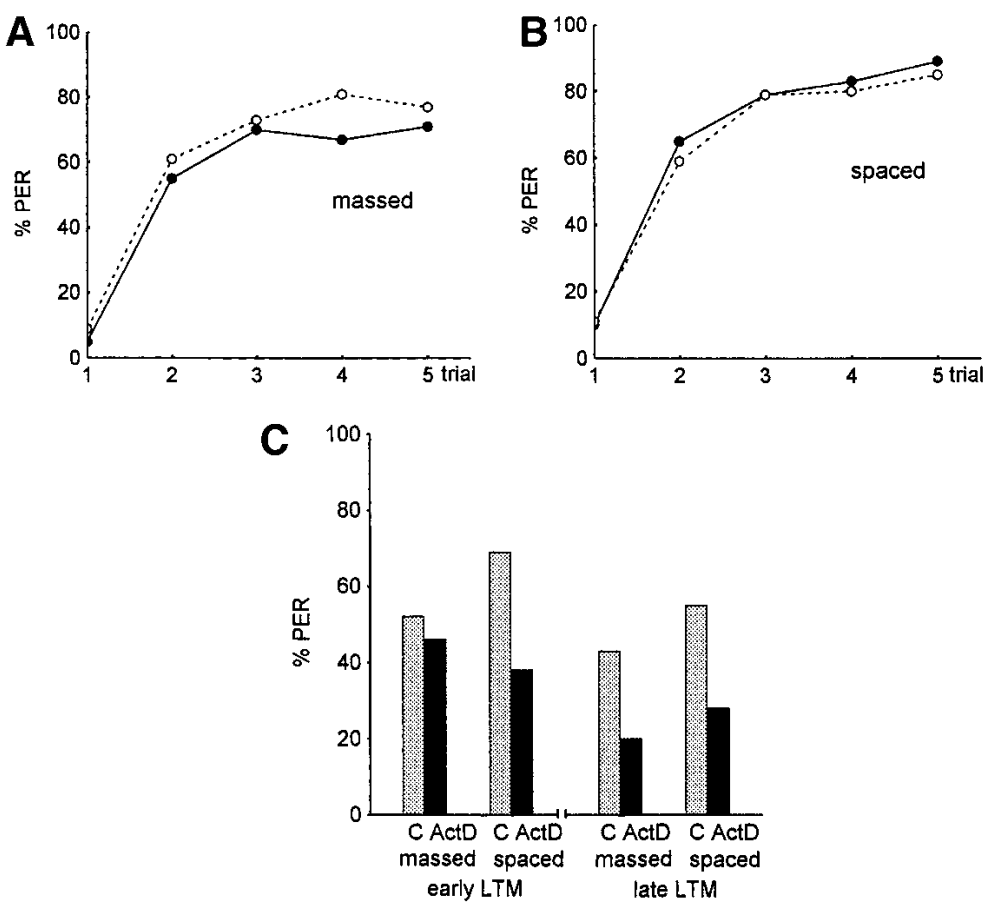

Figure 5 The effect of protein synthesis blockade on acquisition and retention. Experimental groups (- - black column, ActD) were injected with Actinomycin D shortly before conditioning, and control groups (--O--, gray column, C) with saline (see Materials and Methods). ( $A-C$ ) Results of the average of three experiments. (A) Acquisition functions of the massed-conditioned groups. (B) Acquisition functions of the spaced-conditioned groups. (C) Retention scores for the control groups and the ActD groups at the two test intervals, early LTM (1 and 2 d) and late LTM ( 3 and $4 \mathrm{~d}$ after conditioning). In all three experiments the CS was propionic acid, and the standard procedure was applied ( 5 conditioning trials, US: $1.25 \mathrm{M}$ sucrose solution, cumulative testing; control, massed: $n=78$; control, spaced: $n=74$; ActD, massed: $n=78$; ActD, spaced: $n=77$ ).

retention in massed-conditioned animals, and constructive effects in spaced-conditioned animals (Müller and Pilzecker 1900; Hintzman 1974).

Acquisition during massed conditioning may be impaired by habituation to the CS and/or US, by inhibitory learning, and by satiation to the sucrose reward. Habituation to the CS is unlikely, because only a large number of CS repetitions may induce habitation (>200; Bicker and Hühnlein 1994), and CS exposure before conditioning does not affect acquisition (Bitterman et al. 1983), although in a special design a latent inhibitory effect was seen (Chandra et al. 2000). Furthermore, preexposure to the CS does not modulate the time course of memory consolidation after a single trial (Gerber and Menzel 2000). US habituation might be more effective, but many more US repetitions (>20) than those employed during acquisition in the present study are needed to habituate the US-induced proboscis extension response (Braun and Bicker 1992). Acquisition could also be low as a consequence of

spaced-conditioned groups $\left(\chi^{2}=14.80, P<0.0001\right.$, $\left.\mathrm{df}=1\right)$, but not the massed-conditioned groups $\left(\chi^{2}=0.32\right.$, N.S., $\mathrm{df}=1$ ), are significantly different at the first test interval (early LTM, Fig. 5C). At the late LTM test interval both massed- and spaced-conditioned groups have significantly higher retention scores in the control groups as compared to the ActD groups $\left(\chi^{2}=11.74, P<0.001\right.$, $\left.\mathrm{df}=1\right)$. These results indicate that a protein synthesis blockade selectively reduces retention after spaced conditioning during the early LTM period, but affects retention after both massed and spaced conditioning during the late LTM period.

\section{DISCUSSION}

Spaced conditioning leads to both better acquisition and higher retention, particularly at long intervals. This welldocumented phenomenon in animal and human learning (see Introduction) is also found in honeybee proboscis extension response (PER) conditioning. In bees, as in other animals, it may reflect the time-dependent interaction of constructive and destructive phenomena during the process of acquisition and long-lasting memory processing. Destructive effects are believed to dominate acquisition and backward conditioning, a phenomenon demonstrated for olfactory PER conditioning in honeybees (Hellstern et al. 1997), and which has been implicated in trial spacing effects (Ewing et al. 1985). However, inhibitory conditioning should affect acquisition to only a small degree, because the optimal US-CS interval for inhibitory conditioning lies around $15 \mathrm{sec}$, and only little inhibitory conditioning is seen for intervals of $30 \mathrm{sec}$, as used here. Increasing satiation as a consequence of feeding at very short intervals may reduce US-related motivation and thus US strength. It is unlikely that the level of satiation changes during the first few trials because hungry bees are used in the experiments, and each bee can consume up to $60-80 \mu \mathrm{L}$ of sucrose solution. Because the bees were allowed to suck for 1-2 sec and bees imbibe about $1 \mu \mathrm{L} / \mathrm{sec}$ (Núñez 1970), the crop will be filled to less than one-tenth of its capacity. However, acquisition functions of massed-conditioned animals usually rise at 5-6 trials and decline beyond 7-8 trials. The decline could well be caused by a satiation effect, but it cannot be excluded that inhibitory learning (to a minimal extent) or US habituation might also contribute to this latter effect. In any case, a more gradual increase of the early phase of the acquisition

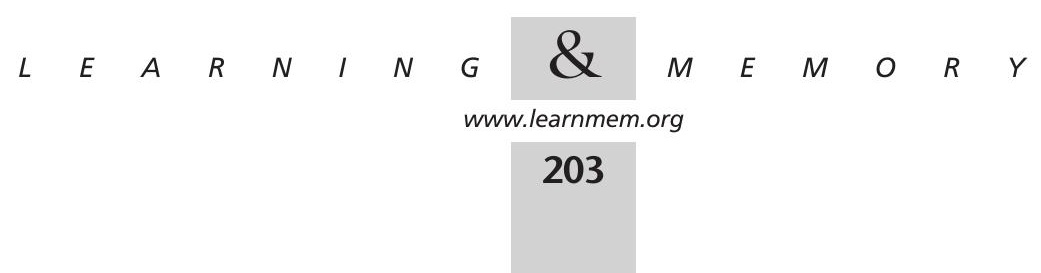


function is unlikely to be fully explained by referring to habituation, inhibitory learning, and satiation. We therefore suggest that the reduction in acquisition results predominantly from acquisition trial spacing.

Low acquisition in massed-conditioned animals (as compared to spaced-conditioned animals) is found in all experimental groups irrespective of the absolute level of acquisition. It is therefore concluded that the reduction in acquisition results predominantly from a lack of consolidation between the trials, a process that appears to work on all levels of learned performance. It has been proposed that interference between consolidation processes induced by consecutive learning trials is destructive, owing to the close temporal proximity of ongoing consolidation and a new learning event, or as a competition between new memories for limited short-term storage space (Hintzman 1974, 1988; Gerber et al. 1998). Our data are consistent with this interpretation, but, as in Hintzman's study, do not allow distinguishing between the two possibilities. In any case, interference or competition between recent and new memory leads to less retention at both shorter and longer intervals, indicating a close correspondence between the immediate outcome of learning and memory addressed at a later time. Therefore, the processes underlying immediate processing in a short-term store between learning trials appear to be directly related to the formation of long-lasting memory that takes place during the hours following the acquisition process (see below). Retrieval from memory, as it happens at any repeated learning trial, has recently been found to induce a new consolidation phase (called reconsolidation; Nader et al. 2000). The timing of consolidation and reconsolidation may, therefore, be a sensitive parameter for the long-term store and may reflect constructive and destructive components in the overall consolidation process.

Spaced conditioning leads not only to higher acquisition and retention, but also to less variable retention at longer intervals. More stable long-lasting memory may result from several conditions: (1) Memory may consolidate over longer periods of time, and because performance saturates, retention scores vary less. There is indeed a tendency toward improved retention scores over the $4 \mathrm{~d}$ tested. (2) Animals may also learn additional stimuli; contextual parameters may be particularly influential. Barnet et al. (1995), in conditioning rats to light or tone with an aversive stimulus, have argued that local contextual stimuli may be more influential for shorter ITI than for longer ITI in modulating conditioned response. Conversely, exposing the animals to the context for longer times during spaced conditioning may favor retention. Fanselow (1990) and Milanovic et al. (1998) found that contextual fear conditioning depends on the time the animal is exposed to the context before aversive stimulation, and fails if the shock follows immediate placement into the training chamber. In our experiments, massed-conditioned animals were kept in the conditioning conditions throughout the experiment, but spaced-conditioned animals were moved to the conditioning location at each trial $30 \mathrm{sec}$ before CS/US pairing. In a previous singletrial study, we found that animals must experience at least a 1-min exposure to the context in order to induce contextual associations by a subsequent sucrose reward (Gerber and Menzel 2000), an effect reminiscent of the "immediate shock effect" in rodents (Fanselow 1990; Milanovic et al. 1998). Given the temporal parameters of the present study, it must for the moment remain unresolved whether and in what way massed and spaced conditioning leads to different levels of contextual learning. Interestingly, retention $3 \mathrm{~min}$ after a single conditioning trial is higher when animals remained in the conditioning context between conditioning and test, than when they were removed from it (Gerber et al. 1998). Therefore, using our present procedures, contextual learning in massed-conditioned animals might improve performance relative to spaced-conditioned animals. On the other hand, Hellstern et al. (1998) suggested that the US triggers two internal reinforcement signals: an early excitatory one that supports CS/US associations during forward (CS-US) pairings, and a relatively long-lasting inhibitory one that supports inhibitory learning during backward (US-CS) pairings. Whether or not that inhibitory reinforcement signal might be able to induce inhibitory contextual memories is at present uncertain. The exact roles of contextual processing for trial spacing effects therefore still need to be resolved.

Animals may learn not only the CS-US association, but also the representation of CS within a larger context. Experiments that systematically vary cue and context (e.g., Rudy and Pugh 1996) indicate that consolidation may differ for the two processes, and therefore the relationship between CS-US memory and representational memory may change over time. There is no indication that context learning in bees triggers a different consolidation process, because visual context does not gain control over the PER response (Gerber and Smith 1998; Gerber and Menzel 2000). Representational learning has not yet been studied in any detail in bees. Sensory preconditioning, which might be indicative of a simple form of representational learning, was demonstrated in bees (Müller et al. 2000), but nothing is known about consolidation processes in sensory preconditioning.

Protein synthesis inhibition selectively reduces early LTM ( 1 and 2 d retention interval) after spaced conditioning, and late LTM ( 3 and $4 \mathrm{~d}$ retention interval) after both massed and spaced conditioning. We found in earlier studies (Menzel et al. 1993; Wittstock et al. 1993; Wittstock and Menzel 1994; Wüstenberg et al. 1998) that LTM after $1 \mathrm{~d}$ is not reduced by protein synthesis inhibition. In these earlier studies and in those by Grünbaum and Müller (1998), bees were conditioned under varying but short intervals, and often only by a few trials. The results reported here dem-

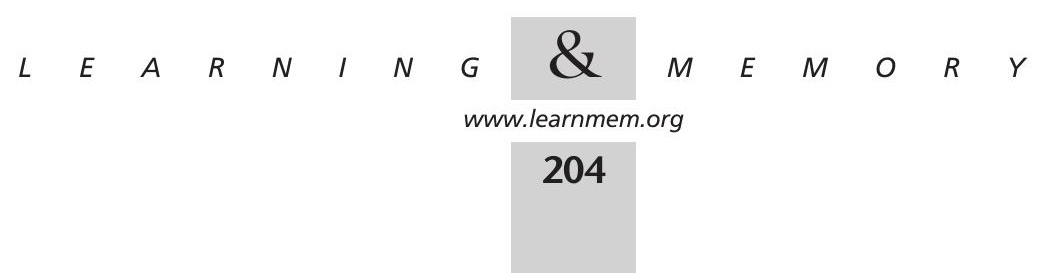


onstrate that retention in spaced-conditioned animals after 1 and $2 \mathrm{~d}$ is reduced by protein synthesis inhibition to a level that is seen in animals after massed conditioning. Therefore, protein synthesis-dependent memory formation after spaced conditioning contributes to an additional form of LTM during the early LTM period that adds to a lasting memory independent of protein synthesis. The finding that retention at the late LTM period after massed conditioning also becomes protein synthesis-dependent indicates that this lasting memory has deteriorated and that the contribution of the protein synthesis-dependent memory predominantly determinates retention. These results resemble those found in Drosopbila for an olfactory avoidance learning task (Tully et al. 1994; Beck et al. 2000) and in Aplysia for long-term facilitation (LTF) of mechanosensory neurons (Mauelshagen et al. 1998). Massed and spaced training in Drosophila induce two different forms of LTM-ARM (amnesia-resistant memory) and LTM-that differ in their duration, dependence on protein synthesis, and the involvement of the radish and CREB genes (Tully et al. 1994; Yin et al. 1994). A model of the underlying molecular mechanisms derived from these results (Yin et al. 1995) proposes two isoforms of the cAMP-dependent transcription factor CREB, an activator and a repressor form. Shortly after conditioning, activator and repressor isoforms of CREB may be equally activated, then the repressor might decay faster, resulting in relatively greater activation of the activator at longer intervals after conditioning. Spaced training would allow for the buildup of reactions induced by the activator, and these may lead to protein synthesis-dependent LTM. An alternative view would relate the spacing effect to rate-limiting reactions (e.g., transcription of genes for structural proteins), and massed training may fail to facilitate such slow processes, because only a short, saturating burst of stimuli is provided.

LTF of a sensory-motor synapse in Aplysia is enhanced and longer-lasting after multiple spaced stimulation of sensory neurons with $5 \mathrm{HT}$ as compared to a single 25-min-long (massed) exposure to 5HT (Mauelshagen et al. 1998). An initial step of spaced 5HT stimulation is a prolonged activation of cAMP-dependent kinase (PKA; Müller and Carew 1998). As in Drosophila, the proportion of activator and repressor isoforms of CREB may determine the strength and duration of LTF (Alberini et al. 1994; Bartsch et al. 1995), and/or a rate-limiting reaction may control LTF formation. The interrelationship between biochemical events elicited by spaced trials and morphological alterations in dendrites has recently been demonstrated in hippocampal neurons of the rat (Wu et al. 2001). Stabilization of the prolonged activity in the MAPK pathway was found to be a requirement for the protrusion of new dendritic filopodia potentially leading to new synaptic contacts.

The picture emerging from these observations is that trial repetition timing is critical for molecular events that lead to either (a) the synthesis of new proteins and new structures underlying LTM and LTF (spaced trials) or (b) ARM and intermediate-term facilitation (massed trials). The two reaction cascades appear to run in parallel in Drosophila, because LTM does not require the activation of those reactions that lead to ARM.

Based on these findings and biochemical data on memory formation in the bee's antennal lobe, a tentative model of molecular events underlying the spacing effect can be proposed for the bee (Fig. 6). Multiple associative trials activate NO synthase and, as a consequence, enhance and prolong the activity of PKA (Müller 1996, 2000). Spaced conditioning may be particularly favorable for persistent activation of PKA and the following reactions leading to gene activation and synthesis of structural proteins. Massed conditioning should be less effective in facilitating these processes, and memory is therefore less strong, deteriorates over time (from early to late LTM), and does not depend on protein synthesis during the early LTM phase. Our finding that the rather low memory during the late LTM phase after massed conditioning can be further reduced by inhibition of transcription indicates that the weak and/or slow processes initiated by massed conditioning are still capable of gene activation, but considerably delayed and at a low level (Fig. 6). In bees, a midterm memory (MTM) exists that supports retention during the first few hours after conditioning, and appears as a parallel memory form because its implementation is not a requirement for the formation of LTM. Grünbaum and Müller (1998) found that blocking the protease-

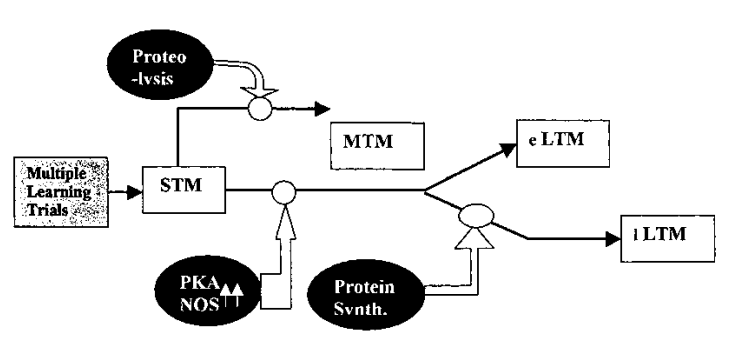

\begin{tabular}{|lll|}
\hline Sec Min & Hours & Davs \\
\hline
\end{tabular}

Figure 6 A model of memory phases and molecular reactions as they might relate to the formation of different forms of memory after massed and spaced conditioning in the honeybee. Multiple associative learning trials lead first to a continuous updating of shortterm memory (STM). Post-trial memory processing proceeds in serial and parallel steps. Midterm memory (MTM) ranges from several hours to $1 \mathrm{~d}$ and is not necessary for the two long-term forms of memory. Early (eLTM) and late (ILTM) long-term memory phases control retention at different times (eLTM: 1-3 d, ILTM: $\geq 3 \mathrm{~d}$ ), but do not depend on each other. STM is characterized by high PKA and $\mathrm{NO}$ synthase activity. PKC is constitutively up-regulated during MTM by a protease-dependent process (PKC1). Protein synthesisdependent up-regulation of PKC (PKC2) is a requirement for ILTM formation. Massed conditioning leads predominantly to eLTM, but also to a small component of ILTM (see text).

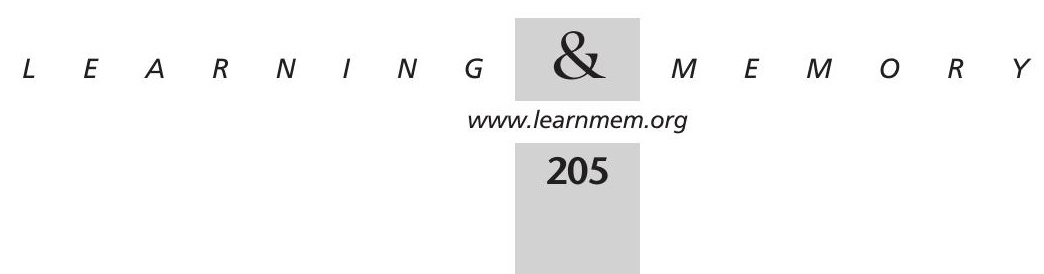


dependent up-regulation of PKC inhibits the formation of MTM but does not interfere with the formation of LTM. It is yet unknown whether massed- and spaced-conditioning protocols have any differential effects on MTM, because retention was not tested in the hours range, and no manipulation of the protease-dependent processes was performed.

The molecular substrates of LTM in the bee are unknown. In particular, it is not yet known whether and how the transcription factor CREB is involved in these processes, although the corresponding gene in the bee has been cloned and sequenced, and 8 cDNAs have been analyzed (Eisenhardt et al. 1998, 1999). An important next step will be to functionally characterize the isoforms of CREB in the bee and to test whether CREB activation also involves PKC. It will also be necessary to examine whether interference with different CREB isoforms has different consequences on retention after massed and spaced conditioning. Because up to now for the bee there are no indications whether the spacing effect is related to the dynamics of CREB isoforms, it will be important to also search for rate-limiting reactions (e.g., synthesis of structural proteins), and translation of existing mRNAs as a potential substrate of early LTM. In this context it is important to remember that ActD blocked transcription in the bee brain only to $65 \%$ (see Materials and Methods), and other drugs with higher efficiency need to be applied.

Memory traces are distributed in the nervous system, and different locations may store different aspect of the memory trace (Carew and Sahley 1986; Squire 1987). In the bee, olfactory memory involves at least the antennal lobe and the mushroom bodies (Hammer and Menzel 1998). Substituting the US in olfactory PER conditioning by local injection of octopamine, we found the usual stepwise acquisition function during multiple-trial conditioning when octopamine was injected into the antennal lobe. When octopamine was injected into the mushroom bodies no such acquisition was seen, but rather, a sudden rise to full memory $30 \mathrm{~min}$ after conditioning. It was concluded that the mushroom bodies might play an essential role in the posttrial consolidation phase. Permanent or transient elimination of the mushroom bodies during massed and spaced conditioning will help test this hypothesis. Permanent mushroom body lesions can be achieved by hydroxy urea treatment of early larvae (Malun 1998), and bees with only partial mushroom bodies can be tested in conditioning experiments (Scheiner et al. 2001). These experiments will contribute to answering the question of what insect mushroom bodies contribute to learning and memory (Heisenberg 1998).

The "paradox of spaced practice" (Björk and Allen 1970 ) is finally accessible to mechanistic analysis. Model systems like Aplysia, Drosophila, the rat, and the bee have helped to sharpen the questions and bring them within the range of neurophysiological experimentation. Working out the molecular and neural mechanisms of this fundamental property of learning in animals is only one part of the task; the other is to understand the biological conditions under which such a property has evolved. Experience spread over time must contain more reliable information worth storing in LTM. Why is this so? A better understanding of the conditions under which learning takes place in the natural environment of a particular species will help us to relate neural mechanisms to biological adaptations.

\section{MATERIALS AND METHODS}

The paradigm applied in this study is classical conditioning of the proboscis extension response (Bitterman et al. 1983). In short, foraging honeybees (Apis mellifera) were collected at the hive entrance the day before conditioning, harnessed in a metal tube, and fed to satiation. The next day, $10 \mathrm{~min}$ before the conditioning started, the bees were checked for the unconditioned response, the reflexive extension of the proboscis after applying sucrose solution to the antennae (standard solution concentration: $1.25 \mathrm{M}$ sucrose). A conditioning trial consisted of forward-pairing the conditioned stimulus (CS, different odorants or other stimuli presented to the antennae for $4 \mathrm{sec}$, see below) with the unconditioned stimulus (US, sucrose solution at standard concentration unless stated otherwise). Reward delivery started $1 \mathrm{sec}$ before odorant offset. The US was delivered by touching the antennae with a toothpick soaked in sucrose solution for $1 \mathrm{sec}$. The bee was then allowed to feed for $2 \mathrm{sec}$; reward delivery thus lasted for a total of $3 \mathrm{sec}$. The intertrial interval (ITI) was either $30 \mathrm{sec}$ (massed conditioning) or 10 min (spaced conditioning); in the first experiment a third group was used ( $3 \mathrm{~min}$ ITI). The animals were left in the conditioning/ training situation throughout the acquisition phase. The number of trials varied from 5 to 12 . After terminating the acquisition phase, the bees were returned to the storage box-a humidified, covered styrofoam box kept at $18^{\circ}-20^{\circ} \mathrm{C}$. The bees were fed to satiation every night (between 6 and 8 p.m.) at least $2 \mathrm{~h}$ after presenting a CS during conditioning or testing. Bees were tested during the early LTM phase ( 1 or $2 \mathrm{~d}$ after conditioning) and the late LTM phase (3 or $4 \mathrm{~d}$ after conditioning). Testing was performed either in a cumulative fashion (the same bee was tested at both times, called same in Table 1) or in a single test (different groups of bees for the two test intervals, called different in Table 1). Table 1 includes only those test animals that survived the whole test period. Fifteen sets of experiments were performed (see Table 1). The odors used as CS were carnation, propionic acid, or 2-hexanol. Two other stimuli were used as CS, mechanical stimulation of the antennae (light strokes with a fine brush) and infrared light (cutoff filter $\leq 720 \mathrm{~nm}$ ) directed toward the antennae. US strength was varied in three steps: $0.5 \mathrm{M}$ (low US), $1.25 \mathrm{M}$ (normal US), and $2.5 \mathrm{M}$ (high US). In applying these different parameters, acquisition varied from 5\% to $97 \%$ asymptotic conditioned responses. Learning performance and retention may also be influenced by uncontrollable variables (the season, weather conditions, colony conditions, nectar, and pollen offerings in the natural environment). These uncontrollable parameters certainly lead to additional variances in the data. We have tried to keep the effects of these variables low, particularly by testing foraging bees departing from the hive. Bees taken from the flight room in wintertime were not used for these experiments, because we observed that they did not develop high long-lasting memory after spaced conditioning.

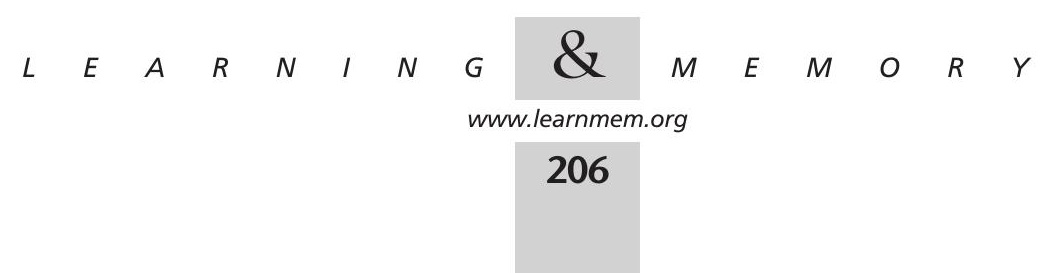




\section{Protein Synthesis Blocking}

Actinomycin D (Sigma) was dissolved in aqua dest, and 1-2 $\mu \mathrm{L}$ was injected into the flight muscle (2-4 $\mu \mathrm{g}$ per animal, which corresponds to 20-40 $\mathrm{mg}$ per $\mathrm{kg}$ body weight). Transcription blocking was determined by the reduction of incorporation of ${ }^{3} \mathrm{H}$-uridine into total RNA (Wüstenberg et al. 1998). A reduction of $65 \%$ was found. Maximal blocking of uridine incorporation was found between $40 \mathrm{~min}$ and $2.5 \mathrm{~h}$. Therefore, the drug solution was injected $40 \mathrm{~min}$ prior to the onset of conditioning. The survival rate was not reduced by drug treatment. We discovered no difference in the animals' general state of health or motivation. In particular, the acquisition rate was not reduced (Fig. 4A).

\section{Statistics}

Because all our data contained dichotomous scores, we used chisquare tests to evaluate the results. Some of the animals tested and trained during acquisition died in the retention phase because of the long test intervals, which are up to $4 \mathrm{~d}$. Authors supporting the use of standard ANOVA emphasize that their method is limited to situations with equal sample sizes for each cell and overall relatively high sample sizes. In our case this limitation would lead to a dramatic loss of information. In cases with more than 2 variables we used log-linear models instead. The term log-linear derives from the fact that, through logarithmic transformations, one can restate the problem of analyzing multiway frequency tables in terms that are very similar to ANOVA. Specifically, one can detect and evaluate the various main effects, interaction effects, and dependencies in the same way as is successfully done with standard ANOVA. First we tested whether there are models that fit the data. If there are no models that fit the data then the respective $\chi^{2}$ statistics are significant $(P<0.05)$. In all of our cases we found that the $\chi^{2}$ statistics were not significant, indicating that the models presented are valid, and the data are not mutually independent.

\section{Single Pilot Experiment Evaluated with a $2 \times 3$ Contingency Table as a Comparison of Three Independent Groups (ITIs)}

To avoid any kind of overinterpretation, in all cases two test intervals (e.g., $3 \mathrm{~min}$ and $10 \mathrm{~min}$ ) were pooled (see Zar 1999, p. 504). This method of combining parameters (e.g., ITIs as in the analysis of Fig. 1) does not, strictly speaking, provide a proper statistical test, but is used to guide the development of statistical hypotheses with a new set of data.

\section{Experiments 1-14}

The interaction of variables was tested using log-linear models and then reviewed as $\mathrm{R} \times \mathrm{C}$ contingency tables (Zar 1999).

\section{ACKNOWLEDGMENTS}

We are most grateful to our colleagues Martin Giurfa and Bertram Gerber for helpful comments and Mary Wurm for editorial assistance. We also acknowledge the helpful comments of two anonymous referees. Data were collected in collaboration with S. Appel, U. Endermann, K. Fritsch, N. Gerberzahn, O. Kowalsky, K. Nägler, M. Niere, N. Plath, A. Rappert, S. Sachse, and A. Schäfer. Support was provided by a DFG grant to R.M. (SFB 515, project no. C5).

The publication costs of this article were defrayed in part by payment of page charges. This article must therefore be hereby marked "advertisement" in accordance with 18 USC section 1734 solely to indicate this fact.

\section{REFERENCES}

Alberini, C.M., Ghirardi, M., Metz, R., and Kandel, E.R. 1994. C/EBP is an immediate-early gene required for the consolidation of long-term facilitation in Aplysia. Cell 76: 1099-1114.

Barnet, R.C., Grahame, N.J., and Miller, R.R. 1995. Trial spacing effects in Pavlovian conditioning: A role for local context. Animal Learn. Behav. 23: 340-348.

Bartsch, D., Ghirardi, M., Skehel, P.A., Karl, K.A., Herder, S.P., and Chen, M. 1995. Aplysia CREB2 represses long-term facilitation: Relief of repression converts transient facilitation into long-term functional and structural change. Cell 83: 979-992.

Beck, C.D., Schroeder, B., and Davis, R.L. 2000. Learning performance of normal and mutant Drosophila after repeated conditioning trials with discrete stimuli. J. Neurosci. 20: 2944-2953.

Bicker, G. and Hähnlein, I. 1994. Long-term habituation of an appetitive reflex in the honeybee. Neuroreport 6: 54-56.

Bitterman, M.E., Menzel, R., Fietz, A., and Schäfer, S. 1983. Classical conditioning of proboscis extension in honeybees (Apis mellifera). $\mathrm{J}$. Compar. Psych. 97: 107-119.

Björk, R.A. and Allen, T.W. 1970. The spacing effect: Consolidation or differential encoding? J. Verbal Learn. and Verbal Behav. 9: 567-572.

Braun, G. and Bicker, G. 1992. Habituation of an appetitive reflex in the honeybee. J. Neurophysiol. 67: 588-598.

Carew, T.J. and Sahley, C.L. 1986. Invertebrate learning and memory: From behavior to molecules. Annu. Rev. Neurosci. 9: 435-487.

Carew, T.J., Pinsker, H.M., and Kandel, E.R. 1972. Long-term habituation of a defensive withdrawal reflex in Aplysia. Science 175: 451-454.

Chandra, S.B., Hosler, J.S., and Smith, B.H. 2000. Heritable variation for latent inhibition and its correlation with reversal learning in honeybees (Apis mellifera). J. Compar. Psych. 144: 86-97.

Ebbinghaus, M. 1885. Über das Gedächtnis. K. Buehler, Leipzig, Germany.

Eisenhardt, D., Müller, U., Kress, H., and Menzel, R. 1998. Cloning of CREB from the honeybee brain. Eur. J. Neurosci. 10: 261.

Eisenhardt, D., Kreß, H., and Menzel, R. 1999. Variability of CREB transcripts in the honeybee brain. In Göttingen Neurobiology Report 1999. Proceedings of the 1st Göttingen Conference of the German Neuroscience Society 1999. Volume II, p. 549. Thieme Verlag, Stuttgart.

Ewing, M.F., Larew, M.B., and Wagner, A.R. 1985. Distribution-of-trials effects in Pavlovian conditioning: An apparent involvement of inhibitory backward conditioning with short intertrial intervals. J. Exp. Psychol.: Animal Behav. Proc. 11: 537-547.

Fanselow, M.S. 1990. Factors governing one trial contextual fear conditioning. Animal Learn. \& Behav. 18: 2213-2217.

Fanselow, M.S. and Tighe, T.J. 1988. Contextual conditioning with massed versus distributed unconditional stimuli in the absence of explicit conditional stimuli. J. Exp. Psychol. 14: 187-199.

Gerber, B. and Menzel, R. 2000. Contextual modulation of memory consolidation. Learning \& Memory 7: 151-158.

Gerber, B. and Smith, B.H. 1998. Visual modulation of olfactory learning in honeybees. J. Exp. Biol. 201: 2213-2217.

Gerber, B., Wüstenberg, D., Schütz, A., and Menzel, R. 1998. Temporal determinants of olfactory long-term retention in honeybee classical conditioning: Nonmonotonous effects of the training trial interval. Neurobiol. Learn. Mem. 69: 71-78.

Grünbaum, L. and Müller, U. 1998. Induction of a specific olfactory memory leads to a long-lasting activation of protein kinase $\mathrm{C}$ in the antennal lobe of the honeybee. J. Neurosci. 18: 4384-4392.

Hammer, M. and Menzel, R. 1998. Multiple sites of associative odor learning as revealed by local brain microinjections of octopamine in honeybees. Learn. Mem. 5: 146-156.

Heisenberg, M. 1998. What do the mushroom bodies do for the insect brain? An introduction. Learn. Mem. 5: 1-10.

Hellstern, F., Malaka, R., and Hammer, M. 1997. Conditioned inhibition in honeybees depends on the US/CS-interval. In Proceedings of the 25th Göttingen Neurobiology Conference (eds. N. Elser and H. Wässle), p. 645. Thieme Verlag, Stuttgart, New York.

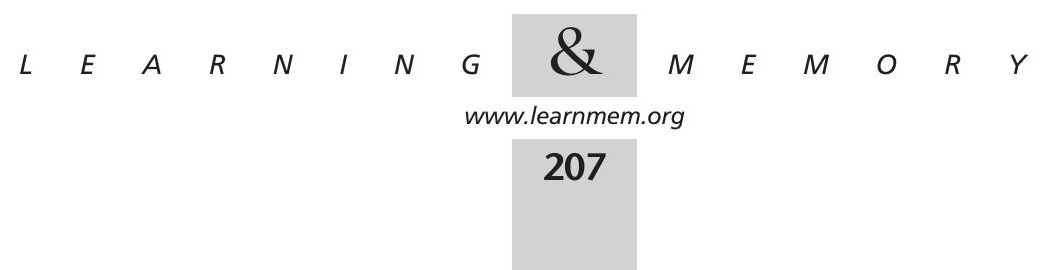


1998. Backward inhibitory learning in honeybees: A behavioral analysis of reinforcement processing. Learn. Mem. 4: 429-444.

Hermitte, G., Pedreira, M.E., Tomsic, D., and Maldonado, H. 1999. Context shifts and protein synthesis inhibition disrupt long-term habituation after spaced, but not massed, training in the crab Chasmagnathus. Learn. Mem. 71: 34-49.

Hintzman, D.L. 1974. Theoretical implications of the spacing effect. In Theories in cognitive psychology: The Loyola symposium (ed. R.L. Solso), pp. 77-99. Lawrence Erlbaum Associates, Potomac, MD.

- 1988. Judgements of frequency and recognition memory in a multiple-trace memory model. Psychol. Rev. 95: 528-551.

James, W. 1890. The Principles of Psychology. Holt, New York.

Jost, A. 1897. Die Assoziationsfestigkeit in ihrer Abhängigkeit von der Verteilung der Wiederholungen. Zeit. Pyschologie 14: 436-472.

Kogan, J.H., Frankland, P.W., Blendy, J.A., Coblentz, J., Marowitz, Z., and Silva, A.J. 1997. Spaced training induces normal long-term memory in CREB mutant mice. Current Biol. 7: 1-11.

Malun, D. 1998. Early development of mushroom bodies in the brain of the honeybee Apis mellifera as revealed by BrdU incorporation and ablation experiments. Learn. Mem. 5: 90-101.

Mauelshagen, J., Sherff, C.M., and Carew, T.J. 1998. Differential induction of long-term synaptic facilitation by spaced and massed applications of serotonin at sensory neuron synapses of Aplysia californica. Learn. Mem. 5: 246-256.

Menzel, R. 1968. Das Gedächtnis der Honigbiene für Spektralfarben. I. Kurzzeitiges und langzeitiges Behalten. Z. vergl. Physiol. 60: 82-102.

. 1979. Behavioral access to short-term memory in bees. Nature 281: 368-369.

-1990. Learning, memory, and "cognition" in honey bees. In Neurobiology of comparative cognition (eds. R.P. Kesner and D.S. Olton), pp. 237-292. Erlbaum, Hillsdale, NJ.

- 1999. Memory dynamics in the honeybee. J. Compar. Physiology A 185: 323-340.

Menzel, R. and Müller, U. 1996. Learning and memory in honeybees: From behavior to neural substrates. Annu. Rev. Neurosci. 19: 379-404.

Menzel, R., Gaio, U.C., Gerberding, M., Nemrava, E.A., and Wittstock, S. 1993. Formation of long-term olfactory memory in honeybees does not require protein synthesis. Naturwiss. 80: 380-382.

Milanovic, S., Radulovic, J., Laban, O., Stiedl, O., Henn, F., and Spiess, J. 1998. Production of the Fos protein after contextual fear conditioning of $\mathrm{C} 57 \mathrm{BL} / 6 \mathrm{~N}$ mice. Brain Res. 784: 37-47.

Müller, D., Gerber, B., Hellstern, F., Hammer, M., and Menzel, R. 2000. Sensory preconditioning in honeybees. J. Exp. Biol. 203: 1351-1364

Müller, G.E. and Pilzecker, A. 1900. Experimentelle Beiträge zur Lehre vom Gedächtnis. Z. Psychol. 1: 1-288.

Müller, U. 1996. Inhibition of nitric oxide synthase impairs a distinct form of long-term memory in the honeybee, Apis mellifera. Neuron 16: 541-549.

2000. Prolonged activation of cAMP-dependent protein kinase during conditioning induces long-term memory in honeybees. Neuron 27: 159-168.

Müller, U. and Carew, T.J. 1998. Serotonin induces temporally and mechanistically distinct phases of persistent PKA activity in Aplysia sensory neurons. Neuron 21: 1423-1434.

Muzzio, I.A., Ramirez, R.R., Talk, A.C., and Matzel, L.D. 1999. Interactive contributions of intracellular calcium and protein phosphatases to massed-trials learning deficits in Hermissenda. Behav. Neurosci. 113: 103-117.

Nader, K., Schafe, G.E., and Le Doux, J.E. 2000. Fear memories require protein synthesis in the amygdala for reconsolidation after retrieval. Nature 406: 722-726.

Núñez, J.A. 1970. The relationship between sugar flow and foraging and recruiting behaviour of honey bees (Apis mellifera L.). Anim. Behav. 18: $527-538$.

Rudy, J.W. and Pugh, C.R. 1996. A comparison of contextual and generalized auditory-cue fear conditioning: Evidence for similar memory processes. Behav. Neurosci. 110: 1299-1308.

Sandoz, J.-C., Roger, B., and Pham-Delègue, M.-H. 1995. Olfactory learning and memory in the honeybee: Comparison of different classical conditioning procedures of the proboscis extension response. C.R. Acad. Sci. Paris Life Sci. 318: 749-755.

Scheiner, R., Weiß, A., Malun, D., and Erber, J. 2001. Responsiveness to sucrose and side-specific tactile antennal learning in honey bees (Apis mellifera) with partial mushroom-body ablations. Animal Cognition 4: 227-235.

Smith, B.H. 1991. The olfactory memory of the honeybee Apis mellifera. I. Odorant modulation of short- and intermediate-term memory after single-trial conditioning. J. Exp. Biol. 161: 367-382.

Spieler, D.H. and Balota, D.A. 1996. Characteristics of associative learning in younger and older adults: Evidence from an episodic priming paradigm. Psychol. Aging 11: 607-620.

Squire, L.R. 1987. Memory and brain. Oxford University Press, New York.

Tully, T., Preat, T., Boynton, S.C., and Del Vecchio, M. 1994. Genetic dissection of consolidated memory in Drosophila. Cell 79: 35-47.

Wittstock, S. and Menzel, R. 1994. Color learning and memory in honey bees are not affected by protein synthesis inhibition. Bebav. Neur. Biol. 62: 224-229.

Wittstock, S., Kaatz, H-H., and Menzel, R. 1993. Inhibition of brain protein synthesis by cycloheximide does not affect formation of long-term memory in honeybees after olfactory conditioning. J. Neurosci. 13: 1379-1386.

Wu, G.-Y., Deisseroth, K., and Tsien, R.W. 2001. Spaced stimuli stabilize MAPK pathway activation and its effects on dendritic morphology. Nature Neurosci. 4: 151-158.

Wüstenberg, D., Gerber, B., and Menzel, R. 1998. Long- but not medium-term retention of olfactory memories in honeybees is impaired by Actinomycin D and Anisomycin. Eur. J. Neurosci. 10: $2742-2745$.

Yin, J.C.P., Wallach, J.S., Del Vecchio, M., Wilder, E.L., Zhou, H., Quinn, W.G., and Tully, T. 1994. Induction of a dominant negative CREB transgene specifically blocks long-term memory in Drosophila. Cell 79: $49-58$

Yin, J.C.P., Del Vecchio, M., Zhou, H., and Tully, T. 1995. CREB as a memory modulator: Induced expression of a dCREB2 activator isoform enhances long-term memory in Drosophila. Cell 81: 107-115.

Zar, J.H. 1999. The interaction of variables was tested using log linear models and then reviewed as $\mathrm{R} \times \mathrm{C}$ contingency tables. In Biostatistical Analysis, pg. 718. Prentice Hall, New York.

Received March 9, 2001; accepted in revised form May 14, 2001. 


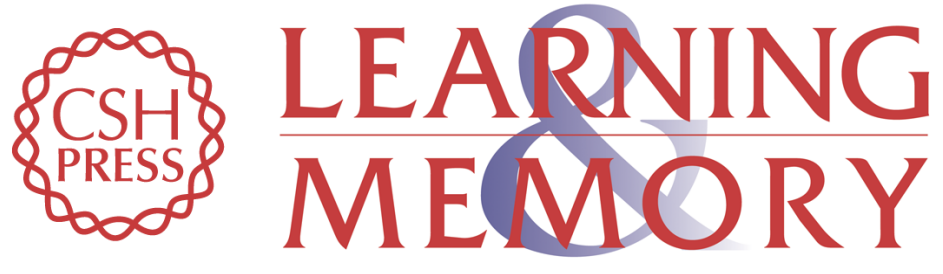

\section{Massed and Spaced Learning in Honeybees: The Role of CS, US, the Intertrial Interval, and the Test Interval}

Randolf Menzel, Gisela Manz, Rebecca Menzel, et al.

Learn. Mem. 2001, 8:

Access the most recent version at doi:10.1101//m.40001

References This article cites 49 articles, 13 of which can be accessed free at: http://learnmem.cshlp.org/content/8/4/198.full.htmI\#ref-list-1

License

Email Alerting Receive free email alerts when new articles cite this article - sign up in the box at the Service top right corner of the article or click here. 